\title{
Genetic heterogeneity within an electrophoretic phenotype of phosphoglucose isomerase in a Japanese population
}

\author{
By CHIYOKO SATOH* AND H. W. MOHRENWEISER \\ Department of Human Genetics, The University of Michigan Medical School, \\ Ann Arbor, Michigan 48109
}

\section{INTRODUCTION}

Human erythrocyte phosphoglucose isomerase (GPI), D-glucose-6-phosphate ketol isomerase (E.C. 5.3.1.9), also referred to as phosphohexose isomerase or glucose phosphate isomerase, is a dimeric enzyme with a molecular weight of 132000 (Tilley, Gracy \& Welch, 1974). It catalyses the interconversion of glucose-6-phosphate and fructose-6-phosphate in the glycolytic pathway. Detter et al. (1968) studying several populations, reported eight different variant phenotypes of human erythrocyte GPI in addition to the usual pattern detected by starch gel electrophoresis. Fitch, Parr \& Welch (1968), studying English and Asian populations, independently reported five kinds of variant phenotypes. Subsequently, the frequency of GPI variants was studied in a variety of populations (Shinoda, 1970; Tariverdian et al. 1971; Terrenato et al. 1971; Omoto \& Blake, 1972; Ishimoto \& Kuwata, 1974). Although the incidence of these variants was in general rare, some ethnic populations showed comparatively high frequencies for these variant phenotypes (Welch, 1971; Ishimoto, 1975; Tanis et al. 1977). In a study of Japanese residing in Hiroshima and Nagasaki, 5 electrophoretic variant phenotypes were observed in 35 unrelated individuals in a sample of 4029 observations (Tanis et al. 1977).

In the present paper, the thermostability of erythrocyte GPI from 27 individuals representing the five variant phenotypes will be described.

\section{MATERIALS AND METHODS}

Glucose-6-phosphate dehydrogenase (G6PD), NADP, dithiothreitol (DTT) were purchased from Calbiochem. Fructose-6-phosphate, 6-phosphogluconate, triethanolamine (TEA) and Triton X-100 were purchased from Sigma. Buffer grade HEPES ( $N$-2-hydroxyethyl piperazine$N$-2-ethansulphonic acid) was purchased from Pierce, Rockford, Ill. Haemolysates were prepared from washed, packed cells by the addition of 4 volumes of lysing buffer (HEPES $5 \mathrm{~mm}$, EDTA $1 \mathrm{~mm}$, DTT $1 \mathrm{~mm}$, Triton X-100 0.06\%, pH 7.4) and centrifugation at $45000 \mathrm{~g}$ for $60 \mathrm{~min}$.

GPI was assayed in the reverse direction (fructose-6-phosphate to glucose-6-phosphate) by coupling the product to glucose-6-phosphate dehydrogenase and measuring the rate of reduction of NADP at $340 \mathrm{~nm}$ at $30^{\circ} \mathrm{C}$ (Noltmann, 1964), utilizing the Miniature Centrifugal Fast Analyzer made by Oak Ridge National Laboratory as described by Burtis et al. 1973. The assay mixture was composed of $1 \mathrm{mM} \mathrm{F-6-P,0 \cdot 1} \mathrm{M} \mathrm{TEA} \mathrm{(pH} \mathrm{8.0),} 1 \mathrm{~mm} \mathrm{NADP}$ and contained 1.0 i.u./ml of G6PD. Haemoglobin (Hb) content was measured by a modified cyan-

* Present Address: Department of Clinical Laboratories, Radiation Effects Research Foundation, Hiroshima, 730, Japan. 
methaemoglobin method (S. Fielek, personal communication). Levels of enzyme activity are expressed as $\mu \mathrm{M}$ of product formed per $\mathrm{g} \mathrm{Hb}$ per $\mathrm{h}$.

Thermostability of GPI was measured by heating the haemolysate diluted with $25 \mathrm{~mm}$ TEA buffer, pH 8.2 (the ratio of packed cells to buffer was 1:29) in glass tubes in a heating block filled with mineral oil for the indicated period, cooling it immediately in ice-water bath, and assaying $10 \mu \mathrm{l}$ of it for the remaining activity. As precipitation of denatured haemoglobin was not observed except for the experiment with added 2-mercaptoethanol, heated haemolysates were usually directly assayed for GPI activity.

Denaturation by urea was performed by incubating a mixture of an equal volume of original haemolysate (ratio of packed cells to lysing solution was $1: 4$ ) and $10 \mathrm{M}$ urea solution at $30^{\circ} \mathrm{C}$. At the end of the indicated period, the mixture was diluted with 3 volumes of $25 \mathrm{mM} \mathrm{TEA}$ buffer, $\mathrm{pH} \mathrm{8.2} \mathrm{so} \mathrm{that} \mathrm{no} \mathrm{further} \mathrm{denaturation} \mathrm{occurred} \mathrm{in} \mathrm{the} \mathrm{diluted} \mathrm{mixture.} \mathrm{No} \mathrm{loss} \mathrm{of} \mathrm{GPI}$ activity was detectable when it was incubated in the presence of $1.25 \mathrm{M}$ urea for several hours.

Inhibition by 6-phosphogluconate was carried out at a fructose-6-phosphate concentration of $1 \mathrm{~mm}$.

Starch-gel electrophoresis was performed according to the method of Detter et al. (1968).

The 35 propositi demonstrating the variant phenotypes were ascertained through a population survey reported previously (Tanis et al. 1977). For this study, specimens from first degree relatives whose electrophoretio phenotypes of GPI were the same as those of the propositi were available for 10 of 27 variants. Washed packed cells which had been stored in liquid nitrogen at the Radiation Effects Research Foundation in Hiroshima for $\frac{1}{2} 4$ years, were shipped in dry ice to the Department of Human Genetics, University of Michigan. Some of the red cells containing variant phenotypes and those of nine Japanese individuals whose GPI is electrophoretically normal, collected shortly before the experiment, were frozen and included among those samples described above. No effect of length of storage period could be ascertained on either level of enzyme activity, heat stability profile or electrophoretic pattern when duplicate samples from the same individual, or samples from first degree relatives sampled at different times were studied.

\section{Heat denaturation}

RESULTS

The thermostability of electrophoretically normal GPI (phenotype 1) and five variant phenotypes detected by the starch-gel electrophoresis in the previous population study of Japanese (Tanis et al. 1977) was examined. Duplicate aliquots of the samples were heated at $47,49.5$ and $52.5{ }^{\circ} \mathrm{C}$ for 10 and $30 \mathrm{~min}$ and the activities remaining were determined as percentages of the original activity of the unheated sample. The means of the remaining activities at each of the six points measured for normal GPI, phenotype 1, in haemolysates of nine Japanese are shown in Table 1 and Fig. 1. The mean level of GPI activity in these individuals before heating was $1979 \pm 45 \cdot 5 \mu \mathrm{M} / \mathrm{g} \mathrm{Hb} / \mathrm{h}$. Heat denaturation curves of normal GPI obtained from haemolysates of individuals whose enzymes seemed to be the most stable or the most labile of the nine individuals and that obtained from a haemolysate $(H)$ which was subsequently utilized as a normal control for all the heat denaturation experiments are also shown in Fig. 1.

The thermostability of GPI in 20 unrelated individuals who showed an identical electrophoretic phenotype, named GPI $14^{-4_{\text {HR }}}$ (Tanis et al. 1977) were examined. GPI $1-4_{\mathrm{HIR}}$ is 


\section{Table 1. Per cent remaining activity of electrophoretically normal GPI from nine Japanese after heating}

$\begin{array}{ccc}\text { Temperature }\left({ }^{\circ} \mathrm{C}\right) & \text { Time }(\mathrm{min}) & \text { Remaining activity }(\%)^{*} \\ 47 & \text { 10 } & 99.5 \pm 0.3 \\ 47 & 30 & 97.2 \pm 0.4 \\ 49.5 & \text { 10 } & 95.4 \pm 0.5 \\ 49.5 & 30 & 85.3 \pm 0.6 \\ 52.5 & \text { 10 } & 74.3 \pm 0.5 \\ 52.5 & 30 & 45.7 \pm 0.5\end{array}$

* Each of the nine samples was assayed in duplicate at each temperature, and the mean was calculated from the data pooled for all samples.

Mean of total GPI activities of nine Japanese samples before heating was $1979 \pm 45 \cdot 5$ (c.v. $=7 \cdot 2)$.
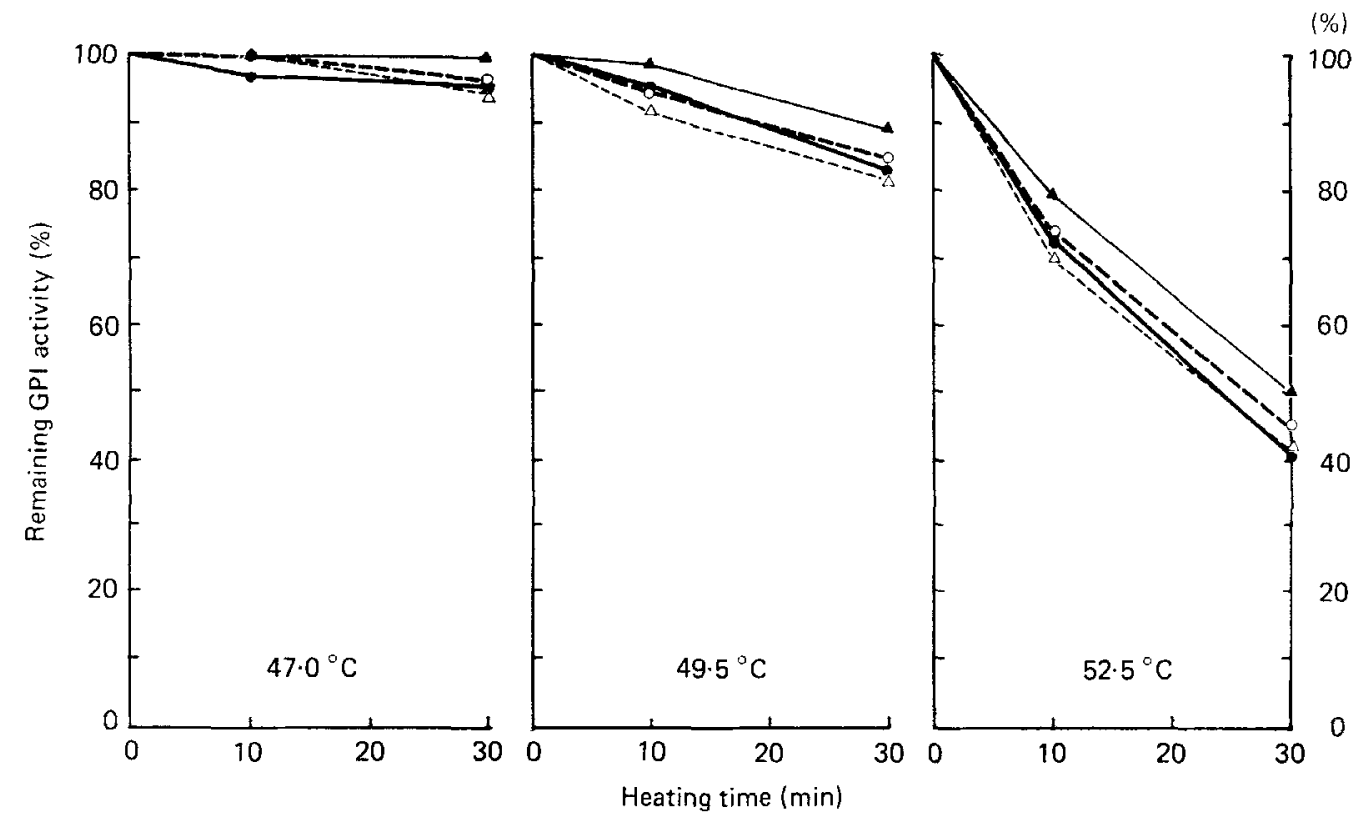

Fig. 1. Per cent remaining enzyme activities of samples of electrophoretically normal GPI (phenotype 1) after heating at various temperatures. The average, the bighest, and the lowest values from duplicate determinations of nine normal GPI samples are shown. $H$ is a sample used as a normal

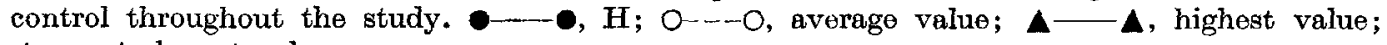
$\triangle \stackrel{\triangle}{\longrightarrow}$, lowest value.

electrophoretically similar to a phenotype named 1-4 by Detter et al. (1968). Examples of the heat stability profiles for selected individuals with those of normal controls $(H$ and $I)$ are presented in Fig. 2 and Table 2. Three distinctly different profiles are observed. Two individuals (nos. 1 and 2) had a variant GPI which exhibited a thermostability profile very similar to that observed for normal GPI. In 16 samples (e.g. nos. 3 and 4), the means of the activities remaining after heating at $49.5{ }^{\circ} \mathrm{C}$ for $30 \mathrm{~min}$ and at $52 \cdot 5{ }^{\circ} \mathrm{C}$ for $10 \mathrm{~min}$ were $67 \cdot 4 \pm 1 \cdot 0 \%$ and $59 \cdot 5 \pm 1 \cdot 3 \%$, respectively, less than those observed in the control samples. The other two samples (nos. 19 and 20) were much more labile than the intermediate group. Accordingly, the 20 samples of GPI 1-4 $4_{\text {HIR } 1}$ phenotype-electrophoretically homogeneous - can be divided into three classes based on their thermostability, that is, stable, labile and very labile, respectively. 
Table 2. Per cent remaining activity of normal and GPI 1-4 ${ }_{\mathrm{HIR}}$ phenotypes after heating

\begin{tabular}{|c|c|c|c|c|c|}
\hline \multirow[b]{2}{*}{ Sample } & & \multicolumn{3}{|c|}{ Remaining activity } & \multirow[b]{2}{*}{$\begin{array}{l}\text { Total GPI } \\
\text { activity } \\
(\mu \mathrm{M} / \mathrm{g} \mathrm{Hb} / \mathrm{h})\end{array}$} \\
\hline & $\begin{array}{l}\text { Thermo- } \\
\text { stability }\end{array}$ & $\begin{array}{c}49.5^{\circ} \mathrm{C} \\
30 \min \\
(\%)\end{array}$ & $\begin{array}{l}52 \cdot 5^{\circ} \mathrm{C} \\
\text { 10 } \min \\
(\%)\end{array}$ & $\begin{array}{c}52 \cdot 5^{\circ} \mathrm{C} \\
30 \min \\
(\%)\end{array}$ & \\
\hline \multirow{3}{*}{$\begin{array}{ll}\text { Normal } & (\text { GPI-I }) \\
\text { H } & \\
\text { I } & \end{array}$} & & & & & \\
\hline & Stable & 83 & 73 & 33 & 1920 \\
\hline & Stable & 80 & 69 & 30 & 1745 \\
\hline \multicolumn{6}{|l|}{ GPI I-4HIR 1} \\
\hline No. I & Stable & 86 & 78 & 39 & 1816 \\
\hline 2 & Stable & 89 & 76 & 39 & 1876 \\
\hline 2-Brother & Stable & 87 & 79 & $4 \mathrm{I}$ & 1827 \\
\hline 3 & Labile & 65 & 58 & 19 & 1510 \\
\hline 4 & Labile & 73 & 62 & 23 & 1779 \\
\hline 5 & Labile & 65 & 53 & 22 & 1866 \\
\hline $5-$ Son & Labile & 64 & 47 & 15 & 1804 \\
\hline 6 & Labile & 66 & 60 & 17 & $175^{6}$ \\
\hline $6-$ Son & Labile & 62 & 57 & 15 & 1605 \\
\hline 6-Daughter & Labile & 66 & 53 & 17 & 1839 \\
\hline 7 & Labile & 72 & 56 & 18 & I 949 \\
\hline 7-Daughter & Labile & 63 & 52 & I5 & I 528 \\
\hline 8 & Labile & 65 & 52 & 14 & 1540 \\
\hline 8 -Daughter & Labile & 70 & 64 & 21 & I425 \\
\hline 9 & Labile & 72 & 65 & 23 & I40I \\
\hline 9-Daughter & Labile & 69 & 56 & 18 & 1433 \\
\hline 19 & Very labile & 53 & $4 \mathrm{I}$ & IO & I 577 \\
\hline I9-Son 1 & Very labile & 54 & 47 & 12 & 1617 \\
\hline $19-\operatorname{Son} 2$ & Very labile & 51 & 44 & II & 1664 \\
\hline I9-Daughter & Very labile & 53 & 44 & IO & 1594 \\
\hline 20 & Very labile & 52 & 46 & I I & ז887 \\
\hline $20-5 o n$ & Very labile & 53 & 46 & I I & 1699 \\
\hline
\end{tabular}

In order to confirm the genetic nature of the heat stability differences, family studies were carried out for these three classes of GPI. The remaining activities of variant GPI phenotypes of the family members which were electrophoretically identical with those of the propositi are shown in Table 2. The heat denaturation profile of the enzyme in the no. 2 family (stable phenotype) is consistent with a genetic trait. Two sons and one daughter of no. 19 (very labile phenotype) showed similar denaturation profiles to that of the propositus. The denaturation curve of the son of no. 20 was very similar to that of the propositus. The thermostability profiles of the enzymes obtained from the family studies for the labile GPI $1-4_{\mathrm{HIR}}$ phenotype were also similar to those obtained from the propositi. Accordingly, the genetic nature of the differences in thermostabilities was confirmed. The range of thermolability of the "labile" class may suggest the possibility of additional heterogeneity in the protein molecules within this large group, although it may be within the range of normal variation for the methodology.

All the phosphoglucose isomerases were examined in the haemolysates heterozygous for normal and variant enzymes and the existence of three kinds of dimers, that is, the normal homodimer, a heterodimer and the variant homodimer, were observed as three bands in starch gel electrophoresis (Tanis et al. 1977). The remaining activities of GPI after heating are the sum of the remaining activities of these three dimers. Starch gel electrophoretic examination of the remaining GPI after heating was carried out for all the samples of GPI 1-4 


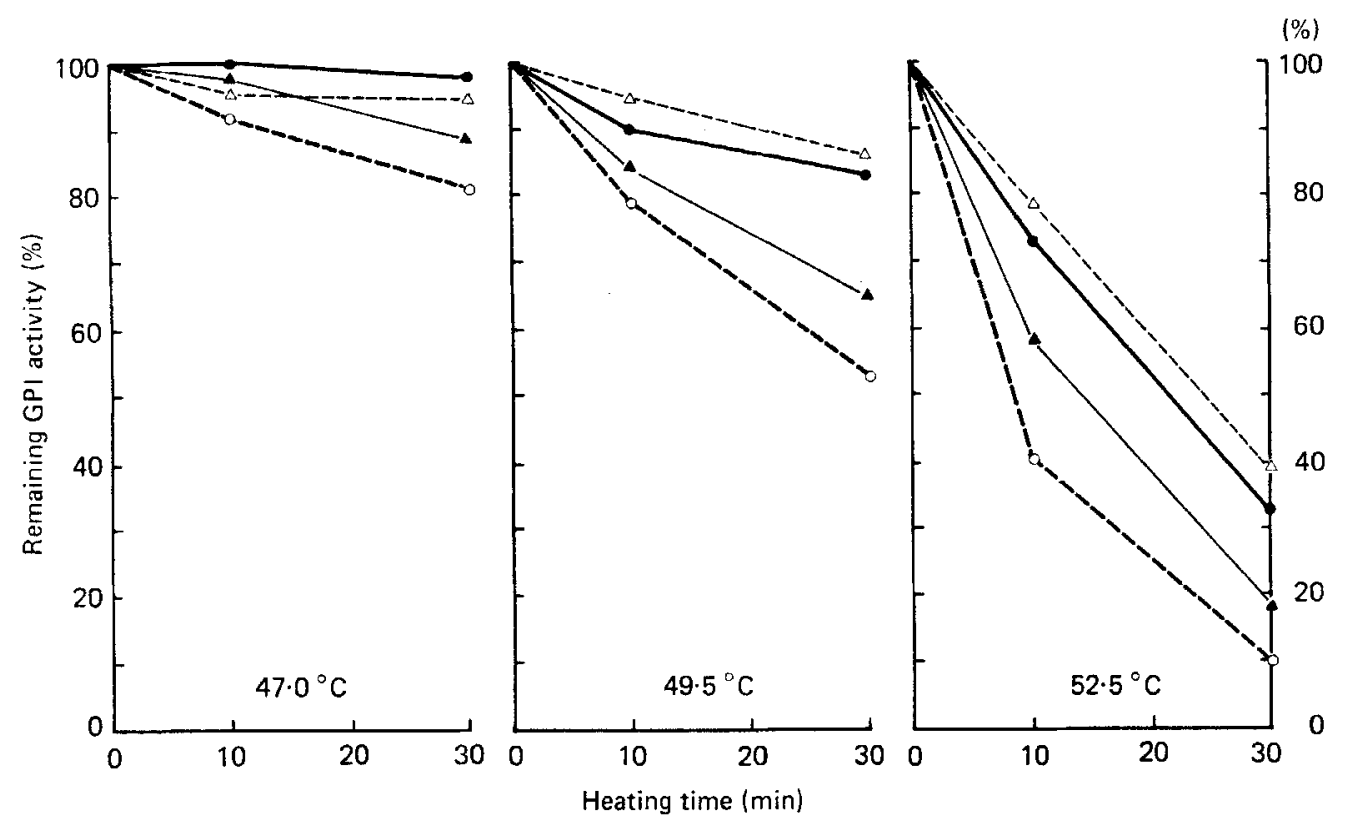

Fig. 2. Per cent remaining enzyme activities of three classes of GPI $1-\mathbf{4}_{\mathrm{HIR}} 1$ phenotype after heating at various temperatures, compared with a normal control $(\mathrm{H})$. $-\mathrm{C}$, Normal $(\mathrm{H})$; $0---0$, no. $19 ; \Delta-\Delta$, no. $3 ; \Delta-\Delta$, no. 1 .

types. As shown in Fig. 3, no. 1, whose PGI is thermostable, showed a variant homodimer and a heterodimer which were more intensely stained than the normal homodimer before heating. After heating for $30 \mathrm{~min}$ at $\mathbf{5 2 . 5}{ }^{\circ} \mathrm{C}$, moderate activity was observed in the variant homodimer and heterodimer, only a slight activity being observed in a normal homodimer. The same result was obtained for no. 2. On the contrary, the very labile GPI of no. 19 (Fig. 3) or no. 20 showed a variant homodimer which stained less intensely than the normal homodimer before heating. The variant homodimer almost disappeared after heating for $10 \mathrm{~min}$ at $52 \cdot 5{ }^{\circ} \mathrm{C}$, when the remaining activity was about $40 \%$. The staining intensities of the normal homodimer and of the variant homodimer of the 'labile' GPI class (e.g. nos. 3 and 4) were almost equal before heating; a decrease in intensity was observed in the variant homodimer after $30 \mathrm{~min}$ at $49.5{ }^{\circ} \mathrm{C}$ or after $10 \mathrm{~min}$ at $52.5{ }^{\circ} \mathrm{C}$, when the remaining activity was approximately $60 \%$. The variant homodimer could not be seen after heating $30 \mathrm{~min}$ at $52.5^{\circ} \mathrm{C}$, when the remaining activity was about $20 \%$. These observations coincide with the results obtained in the heat denaturation experiments and indicate that thermostability is a characteristic of the variant GPI and not the normal GPI.

The other four variant phenotypes detected by starch gel electrophoresis in this population were also examined for thermostability and the results are shown in Table 3 . Phenotype 1-2 ${ }_{\text {NGS } 1}$ in two individuals and a family member of one of them was more stable than the normal GPI. After $30 \mathrm{~min}$ at $52.5^{\circ} \mathrm{C}$, the remaining activity was approximately $10 \%$ higher in the GPI-2 NGS $1_{1}$ phenotype than that in normal GPI. GPI phenotypes $1-3_{\mathrm{HIR}_{1}}$ and $1-5_{\mathrm{NGS}_{1}}$ seemed to be as stable as the normal GPI. When three samples of the GPI 1-5 $\mathbf{5}_{\mathrm{HIR}}$ phenotype were examined, enzymes in two of them (nos. 25 and 26) showed almost the same pattern of heat

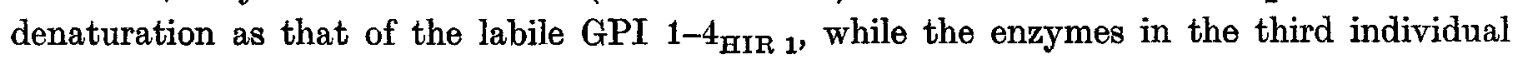



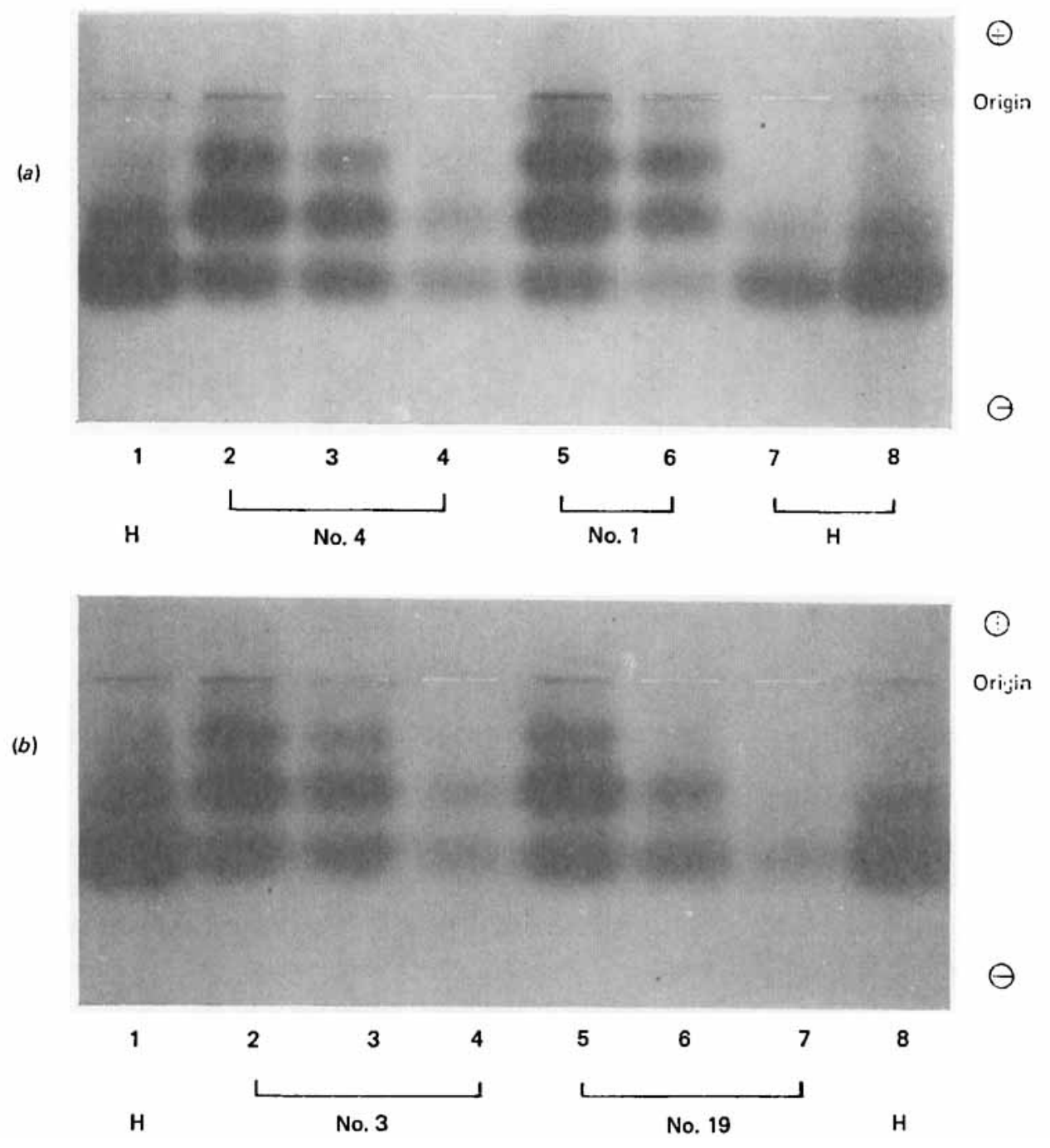

Fig. 3. Starch gel electrophoresis patterns of normal and three kinds of GPI 1-4 $\mathbf{4}_{\text {HIR } ~}$ variants before and after heating. (a) Wells 1 and 8: unheated normal GPI (H); well 2, unheated no. 4

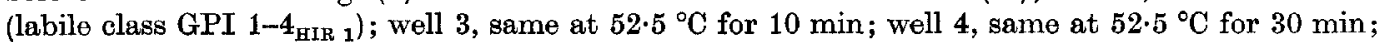
well 5, unheated no. 1 (stable class GPI $1-4_{\text {HIR } 1}$ ); well 6 , same at $52.5{ }^{\circ} \mathrm{C}$ for $30 \mathrm{~min}$; well 7 , normal GPI (H) at $52.5{ }^{\circ} \mathrm{C}$ for $30 \mathrm{~min}$. (b) Wells 1 and 8 , unheated normal GPI $(\mathrm{H})$; well 2 , unheated no. 3 (labile class GPI 1-4 ${ }_{\mathrm{HIR}}$ ); well 3, same at $52.5^{\circ} \mathrm{C}$ for $10 \mathrm{~min}$; well 4 , same at $52.5{ }^{\circ} \mathrm{C}$ for $30 \mathrm{~min}$; well 5 , unheated no. 19 (very labile class GPI $1-4_{\text {aIr } 1}$ ); well 6 , same at $52.5{ }^{\circ} \mathrm{C}$ for $10 \mathrm{~min}$; well 7 , same at $52 \cdot 5{ }^{\circ} \mathrm{C}$ for $30 \mathrm{~min}$.

(no. 27) and his daughter showed almost the same denaturation curves as that of the normal GPI. Because GPI $5_{\text {NGS } 1}$ and GPI $5_{\text {HIR } 1}$ have different electrophoretic mobilities in the presence or absence of added 2-mercaptoethanol (Tanis et al. 1977), their thermostability was determined with and without $0.1 \%$ of 2 -mercaptoethanol. Although a small amount of precipitation of denatured haemoglobin was observed when 2-mercaptoethanol was added and it was excluded from heated samples by centrifugation and their electrophoretic patterns showed the effect of the added reducing reagent, no difference was observed in their heat denaturation curves. At present, there are no other data which clearly confirm that the observed difference 
Table 3. Per cent remaining activity of various GPI phenotypes after heating

\begin{tabular}{|c|c|c|c|c|c|}
\hline \multirow[b]{2}{*}{ Sample } & \multirow[b]{2}{*}{$\begin{array}{l}\text { Electrophoretic } \\
\text { phenotype }\end{array}$} & \multicolumn{3}{|c|}{ Remaining activity } & \multirow[b]{2}{*}{$\begin{array}{c}\text { Total GPI } \\
\text { activity } \\
(\mu \mathrm{M} / \mathrm{g} \mathrm{Hb} / \mathrm{h}\end{array}$} \\
\hline & & $\begin{array}{c}49 \cdot 5{ }^{\circ} \mathrm{C} \\
30 \min \\
(\%)\end{array}$ & $\begin{array}{c}52.5^{\circ} \mathrm{C}, \\
\text { 10 min } \\
(\%)\end{array}$ & $\begin{array}{c}52 \cdot 5^{\circ} \mathrm{C}, \\
30 \min \\
(\%)\end{array}$ & \\
\hline Normal (H) & $\mathbf{I}$ & 83 & 73 & 33 & 1920 \\
\hline No. 21 & $1-2_{\text {NQB } 1}$ & 83 & 71 & 46 & 2165 \\
\hline 22 & $1-2_{\text {NGS I }}$ & 85 & 73 & 43 & 2126 \\
\hline 22-Daughter & $I-2_{\text {NGS } 1}$ & 86 & 76 & $4 I$ & 2031 \\
\hline 23 & $I-3 \mathrm{HIR} 1$ & 79 & 69 & 33 & 1926 \\
\hline 24 & $I-5_{\text {NGS } 1}$ & 78 & 66 & 27 & $246 \mathrm{I}$ \\
\hline 25 & $I-5$ HIR 1 & 78 & 63 & 17 & 2041 \\
\hline 26 & I-5 5 WR 1 & 73 & 62 & 23 & 1806 \\
\hline 27 & $\mathrm{I}-5 \mathrm{HIR} I$ & 85 & 74 & 34 & 1432 \\
\hline 27-Daughter & $I-5$ HIR I & 83 & 74 & 34 & $\simeq 635$ \\
\hline
\end{tabular}

of thermostability within GPI $1-5_{\operatorname{HIR}}$ phenotype is real, because not enough packed cells of the first two individuals remained to carry out other experiments. The starch gel electrophoresis of the heated haemolysates again confirmed that stability against heat is a characteristic intrinsic to the electrophoretically variant proteins.

\section{Urea denaturation}

Two samples from each of the three classes of GPI $1-4_{\text {HIR } 1}$ phenotypes with different thermostability and two with normal GPI were examined for the loss of activity of the GPI by 5 ur urea denaturation. The denaturation procedures were carried out in three replicates and GPI was assayed three times for each replicate. The possibility of heat denaturation at $30^{\circ} \mathrm{C}$ was excluded since no difference in activity of GPI was observed in a mixture of a haemolysate and water and a haemolysate in $1.25 \mathrm{M}$ urea solution at 0 and $30^{\circ} \mathrm{C}$ for $45 \mathrm{~min}$. Results are shown in Table 4 . The order of the remaining activities at 15 and at $45 \mathrm{~min}$ is the same as that which obtained for thermostability. Nevertheless, when the values obtained from two persons with normal GPI phenotype were compared with those obtained from variant GPI phenotypes, one normal GPI (H) was similar to stable GPI 1-4 $4_{\mathrm{HIR}}$ phenotype and the other

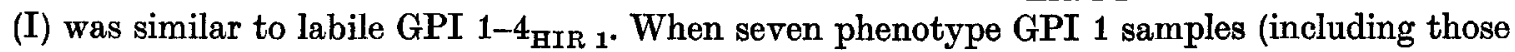
of $\mathrm{H}$ and $\mathrm{I}$ ) were examined for the denaturation of their GPI by urea, remaining activities at 45 min were observed to be in a range of $47-61 \%$. GPI of $H$, which retained $61 \%$ of original activity in the previous experiment, again retained $61 \%$ of the original activity, while GPI of $\mathrm{I}$, which retained $51 \%$ of original activity in the previous experiment, retained $55 \%$. When the remaining activities of these two normal GPI samples (H and I) after heat denaturation were compared, the values of $H$ were usually higher than those of $I$, but the differences were $3-4 \%$ of the original activity at $52.5^{\circ} \mathrm{C}$, and they seemed to be in the range of experimental error. All of these results indicate that the stability of the enzymes to denaturation with $5 \mathrm{M}$ urea in the conditions we used, was similar to the heat stability profile of the various proteins. 
Table 4. Per cent remaining activity of normal and GPI 1-4 $4_{\mathrm{HI}}$ phenotypes after treatment with $5 \mathrm{M}$ urea at $30^{\circ} \mathrm{C}$

$\begin{array}{cccc}\text { Samples } & \begin{array}{c}\text { Thermo- } \\ \text { stability }\end{array} & \begin{array}{c}\text { I5 min } \\ (\%)\end{array} & \begin{array}{c}45 \mathrm{~min} \\ (\%)\end{array} \\ \text { Normal (H) } & \text { Stable } & 81 & 61 \\ \text { Normal (I) } & \text { Stable } & 76 & 51 \\ \text { No. } 1 & \text { Stable } & 82 & 62 \\ 2 & \text { Stable } & 81 & 62 \\ 3 & \text { Labile } & 77 & 52 \\ 4 & \text { Labile } & 76 & 48 \\ 19 & \text { Very labile } & 64 & 30 \\ 20 & \text { Very labile } & 66 & 40\end{array}$

\section{Inhibition by 6-phosphogluconate}

Phosphoglucose isomerases of the same eight individuals whose samples were examined for denaturation by urea were assayed in the presence of various concentrations of 6-phosphogluconate. No differences were observed in the percentage inhibition among the normal and the three classes of the GPI $1-4_{\text {HIR } ~}$ phenotype.

\section{DISCUSSION}

Although the electrophoretic approach has represented a very major step in the detection of variability at the protein level, its limitations are well known. The major constraint is the necessity for the amino acid substitution to involve a charge alteration, a constraint which is estimated to occur in only 1 of 4 amino acid changes. Haemoglobin is an excellent example of single electromorphs concealing many different amino acid substitutions. Until recently, variation within an electromorph was detected almost exclusively by fingerprinting and sequencing techniques which are only useful when purified protein is available in relatively large amounts.

The present study on identification of previously undetected variation within a single electrophoretic class of GPI variants demonstrates the utility of heat stability studies in detecting amino acid substitutes which do not alter the electrophoretic mobility of the variant protein. The demonstration of three classes of variants within the GPI $1-4_{\text {HIR }}$ group and the suggestion of two classes within the GPI $1-5_{\mathrm{HIR}}$ group is similar to the results obtained by Bernstein, Throckmorton \& Hubby (1973), Singh, Hubby \& Lewontin (1974), Singh, Hubby \& Throckmorton (1975), Singh, Lewontin \& Felton (1976), and Thörig, Schoone \& Scharloo (1975) who utilized heat stability techniques to subdivide electromorphs in other enzyme systems in Drosophila.

The susceptibility to $5 \mathrm{M}$ urea of the various GPI $1-4_{\text {HIR } 1}$ variants parallels their susceptibility to heat denaturation, although the magnitude of the differences are not as large. The data on urea and heat stability would indicate that the amino acid substitutions, although conferring similar charge changes to each of the variant proteins, result in altered conformation of the protein molecule in each instance. The difference in stability was always manifested in the variant protein band when treated samples were examined by electrophoresis. The lack of 
effect on the kinetic properties of the enzyme would indicate that structural alteration does not affect the active sites of the enzyme. Similarly Vives-Corrons et al. (1975) and Van Biervliet, Van Milligen-Boersma \& Staal (1975a), Van Biervliet et al. (1975b) reported that no changes in the kinetic properties were observed in GPI variants detected by electrophoresis although these individuals were characterized by GPI deficiency and non-spherocytic haemolytic anaemia.

This study demonstrates that stability studies designed to detect structural alterations manifested by changes in protein conformation are helpful in determining further variation within electrophoretic classes of proteins.

\section{SUMMARY}

The thermostability of the five kinds of electrophoretically variant phenotypes of GPI which were found in Japanese in a previous study (Tanis et al. 1977) was examined. The most frequently found variant phenotype, termed GPI 1-4 HIR 1, observed in 20 individuals could be divided into three distinct classes on the basis of thermostability characteristics. These classes were termed 'stable', 'labile', and 'very labile'. 'Stable' lost approximately 20 and $60 \%$ of its original activity after heating 10 and $30 \mathrm{~min}$ at $52 \cdot 5{ }^{\circ} \mathrm{C}$, respectively, while normal GPI lost approximately 30 and $\mathbf{7 0} \%$ of its original activity. 'Labile' lost approximately 40 and $80 \%$, and 'very labile' lost approximately 55 and $90 \%$ of its original activity under the same heating conditions. Flectrophoresis showed that thermostability was a characteristic of the variant protein molecule but not of the electrophoretically normal molecule. The order of the stability of these three kinds of variants against $5 \mathrm{~m}$ urea was the same as that of their thermostability. No difference against inhibition by 6-phosphogluconate was observed among the normal and the variant phosphoglucose isomerases. Family studies confirmed the genetic nature of the thermo- and urea stability differences among the affected individuals.

We are indebted to many individuals who so generously donated their blood samples, and without whose co-operation this study would not have been possible. We are grateful to Dr Kazuaki Goriki and Takeshi Kageoka for collecting blood samples of the GPI variants. We thank Dr J. V. Neel for helpful discussion of this work and Miss Marrianne Morrow for her excellent technical assistance for the electrophoretic studies. Financial support for the study derived from Contract EY-77-C-02-2828 with the Energy Research and Development Administration, Washington, D.C.

\section{REFERENOWS}

Bernstern, S. C., Throckmortor, L. H. \& HuBby, J. L. (1973). Still more genetic variability in natural populations. Proc. natn. Acad. Sci. U.S.A. 70, 3928.

Burtis, C. A., Johnson, W. F., Mailen, J. C., Overton, J. B., Tiffary, T. O. \& Watsky, M. B. (1973). Development of an analytical system around a miniature fast analyzer. Clin. Chem. 19, 895.

Detter, J. C., Ways, P. O., Giblett, E. R., Baughan, M. A., Hopkinson, D. A., Povey, S. \& Harris, H. (1968). Inherited variations in human phosphohexose isomerase. Ann. Hum. Genet., Lond. $31,329$.

Fitch, L. I., PaRr, C. W. \& Welch, S. G. (1968). Phosphohexose isomerase variation in man. Biochem. J. $110,56$.

Isнiмото, G. (1975). Red cell enzymes. In Human Adaptability, vol. II (ed. S. Watanabe, S. Kondo \& E. Matsunaga), p. 109. Tokyo: University of Tokyo Press.

Ishimoto, G. \& Kuwata, M. (1974). Electrophoretic variants of red cell phosphohexose isomerase in Japan. Jap. J. Hum. Genet. 18, 356.

Noltmans, E. A. (1964). Isolation of crystalline phosphoglucose isomerase from rabbit muscle. J. biol. Chem. $239,1545$. 
Омото, K. \& Bl.AkE, N. M. (1972). Distribution of genetic variants of erythrocyte phosphoglycerate kinase (PGK) and phosphohexose isomerase (PHI) among some population groups in south-east Asia and Oceania. Ann. Hum. Genet., Lond. 36, 61.

SHINodA, T. (1970). Inherited variations in red cell phosphoglucose isomerase among Japanese. Jap. J. Hum. Genet. 15, 159.

Sinat, R. S., HubBy, J. L. \& Lewontin, R. C. (1974). Molecular heterosis for heat-sensitive enzyme alleles. Proc. natn. Acad. Sci. U.S.A. 71, 1808.

Singh, R. S., HubBy, J. L. \& Throckmorton, L. H. (1975). The study of genetic variation by electrophoretic and heat denaturation techniques at the octanol dehydrogenase locus in members of the Drosophila Virilis group. Genetics, N.Y. 80, 637.

Singh, R. S., Lewontin, R. C. \& Felton, A. A. (1976). Genetic heterogeneity within electrophoretic 'alleles' of xanthin dehydrogenase in Drosophila Pseudoobscura. Genetics, N.Y. 84, 609.

Tanis, R. J., Ueda, N., Satoh, C., FerReld, R. E., Kishimoto, S., Neel, J. V., Hamilton, H. B. \& Ohno, N. (1977). The frequency in Japanese of genetic variants of 22 proteins. IV. Acid phosphatase, NADPisocitrate dehydrogenase, peptidase $\mathbf{A}$, peptidase $\mathrm{B}$ and phosphohexose isomerase. Ann. Hum. Genet., Lond. $41,419$.

Tariverdian, G., ObracaJ, H., Rimter, H. \& Wendt, G. G. (1971). Zur Populations-genetik der Phosphoglucose isomerase. Humangenetik 11, 169.

Terrenato, L., Saxtolamazza, C., Piacentint, E., Ulizzi, L. \& Stirati, G. (1971). Two human red cell phosphohexose isomerase variants in a sample from the population of Rome. Humangenetik 14, 162.

Thörig, G. E. W., Schoone, A. A. \& Scharloo, W. (1975). Variation between electrophoretically identical alleles at the alcohol dehydrogenase locus in Drosophila melanogaster. Biochem. Genet. 13, 721.

Tilley, B. E., GraCY, R. W. \& WeLCH, S. G. (1974). A point mutation increasing the stability of human phosphoglucose isomerase. J. biol. Chem. 249, 4571.

van Biervitet, J. P. G. M., van Mrluigen-Boersma, L. \& StraAl, G. E. J. (1975a). A new variant of glucose phosphate isomerase deficiency (GPI-UTRECHT). Clin. Chim. Acta 65, 157.

vai Biervltet, J. P., Vlug, A., Battstra, H., Rotmeveet, J. J., de Vaai, G. A. M. \& StaAt, G. E. J. $(1975 b)$. A new variant of glucose phosphate isomerase deficiency. Humangenetik 30, 35.

Vives-Corrons, J. L., Rozman, C., Kafr, A., Carrera, A. \& Trignner, J. (1975). Glucose phosphate isomerase deficiency with hereditary hemolytic anemia in a Spanish family: Clinical and familial studies. Humangenetik 29, 291.

WeLCH, S. G. (1971). Qualitative and quantitative variants of human phosphoglucose isomerase. Hum. Hered. 21, 467. 